\title{
Oil and Other Pressing Matters
}

T am pleased to introduce this full and exciting fall issue of Ecological Restoration. Guest editor Roberto Lindig Cisneros has pulled together eight full-length articles and four Restoration Notes describing a diverse range of restoration initiatives in Mexico. As he points out in his editorial in this issue, the country's cultural diversity is tightly linked with its biodiversity, and as the contributions in this issue reflect, anyone working on restoration efforts in Mexico is familiar with the need to identify the role of communities in restoration and to work with local people in order to foster participation and ownership of restoration projects.

It is quite appropriate, therefore, that we also feature a piece on "biocultural and ecogastronomic restoration" by Gary Paul Nabhan, DeJa Walker, and Alberto Mellado Moreno. The authors report on work being carried out by the Renewing America's Food Traditions Alliance, which identifies the overlaps in ecological restoration and cultural recovery in North America. While some of these community-based projects have been generated by First Nations or tribes seeking to reestablish their food security and sovereignty, most of the initiatives are cross-cultural and intergovernmental in nature. This is a rich area with great potential for increasing community commitment to restoration efforts and to expanding the social justice of restoration projects. But does ecological restoration need also to consider nonhuman species "for their own sake"? William Jordan III reflects on this question in a sidebar to the article on page 272 .

In this issue we also bring you an article on the impacts of restoration on insect pollinators in southwestern U.S. forests by Susan Nyoka, a piece on controlling rhizome apical dominance in reed canarygrass by Craig Annen, and a research report on the impacts of herbicides on cogongrass in Florida by Eric Holzmeuller and Shibu Jose.

My excitement over the diverse and rich content in this issue has been dimmed by the expanding "blob of death" in the Gulf of Mexico, as the oil spill there was recently referred to by a research scientist. As I write this editorial (in June), BP's broken well has released somewhere between 300 and 570 million liters (40 and 120 million gallons) since the rig exploded on April 20, killing 11 people. The company hopes to have the leak under control by August

Ecological Restoration Vol. 28, No. 3, 2010

ISSN 1522-4740 E-ISSN 1543-4079

(C2010 by the Board of Regents of the University of Wisconsin System. or September. This spill puts to shame the worst oil spills on record, which include the Ixtoc I oil well responsible for 413,000 tons of oil flowing into the Gulf of Mexico after an explosion between June 1979 and March 1980. Much worse and not an accident at all, the Gulf War oil spill was an estimated 8 million barrels of oil $(1,240,000-1,400,000$ tons) spewed into the Persian Gulf after Iraqi forces opened valves of oil wells and pipelines as they retreated from Kuwait in 1991. The oil slick was estimated to be $163 \mathrm{~km}$ by $68 \mathrm{~km}$ and $13 \mathrm{~cm}$ thick.

Looking over the public and scientific media that has developed in response to the ongoing Gulf of Mexico spill, we are reminded of several things: 1) this was predictable (and predicted); 2) this will not be the last oil-related disaster in the Gulf; 3) this is but only the most recent in a decades-long onslaught on the Louisiana coastal environment in the name of energy development; 4) oil spill restoration efforts are fraught, the technologies have changed little in the last 20 years, and often the best course of action is to do nothing; and 5) we have too little scientific information to predict the environmental impacts of this deepwater spill and to develop targeted restoration plans.

The Gulf of Mexico is the most explored, drilled, and developed of offshore reserves. There are nearly 4,000 active platforms (out of 6,400 worldwide) servicing 35,000 wells, and 46,000 km of pipelines. More than 50,000 wells have been drilled in coastal Louisiana (a.k.a. "America's Wetland"), accessed by 13,000 km of canals crisscrossing the swamps, marshes, and bayous. Experts estimate that mineral extraction is directly responsible for one-third of all the coastal wetland loss and land subsidence.

Furthermore, the infrastructure supporting this exploration, drilling, and development, highly concentrated in coastal Louisiana and eastern Texas, includes oil refineries, petrochemical and gas processing plants, supply and service bases for offshore oil and gas production units, platform construction yards, pipeline yards, and other industry-related installations. That is a lot of jobs-some 320,000 of them in Louisiana alone. This infrastructure exists, of course, to provide us with the oil and gas around which we've built our lives. Altogether, this adds up to a great deal of path dependency, or "addiction" to use an oftquoted term. In other words, oil is a hard habit to break for many reasons.

We did not arrive here as the result of some inevitable march of progress, or a deity-willed mandate that the U.S. develop to be the biggest energy hog in the world. It is 
useful to analyze the oil spill, to consider the historical trajectory of deepwater oil development as it has been defined by the physical geography of the Gulf, by federal oil-leasing politics, by the strength of the environmental lobby on the eastern and western U.S. coasts and the strength of the oil lobby in the south. Just as in all restoration work, history helps us understand what and how human and natural changes occur, and what future trajectories are more, and less, easily attained. Although technological development often has the feel of inevitability, for example, the argument has been made that deepwater drilling in the Gulf of Mexico is the result of the long-term decline of the Gulf as an oil resource. Tyler Priest (2007) has argued that as shallower well fields dried up, companies pushed into deeper and deeper water, but only with the encouragement of federal government policy. In addition, only the largest companies with the deepest pockets have been able to move into this new territory, and one of the strategies for managing the increasing risk has been to contract out different parts of the enterprise to other companies that will also assume risk. Hence, the Swiss company Transocean owns the now-sunk Deepwater Horizon oil rig.

Critical incentive for taking on all this risk has been provided by the federal government, anxious for the revenue from leasing public land for oil exploration and development. Under President Reagan's Secretary of Interior James Watt, a long-term downward trend in deep oil drilling was reversed when he opened up even more of the public sea floor to oil exploration and drilling. Watt instituted a so-called "areawide leasing" system offshore, which put up to 20 million hectares of the central Gulf of Mexico up for grabs, as opposed to tracts specifically nominated and offered by the U.S. Department of Interior under a tract-selection system. Companies could bid on any tract they wanted in the planning area rather than choosing from a limited number of carefully selected ones, and they had greater control over large prospects. Beginning in 1983, federal revenue from oil leases fell, but deepwater oil production rose steeply and big oil made big money. It is really hard not to connect this shrinking of government oversight and the oil developers' strategy of spreading risk among lots of players with sloppy emergency plans and the utter haplessness we have witnessed on the part of BP to control the leak from its deepwater oil well.

In his "Gulf Coast Restoration Plan" announced in early June, President Obama outlined several reasonable steps, including increasing government oversight of offshore drilling and activating the many restoration plans already on the books (see Dave Egan's post-Katrina editorial in the December 2005 issue of this journal for a description of restoration programs)." Congress has authorized wetlands restoration projects in the past, but follow-through has been spotty. The $\$ 500$ million appropriated for restoration after Katrina has largely been spent on levees and water pumps instead of rebuilding marshes. The 1990 Coastal Wetlands Planning, Protection and Restoration Act provides $\$ 80$ million a year, but that's small in light of the cost of truly revitalizing the region, which some estimate at $\$ 30$ billion over the next $15-20$ years. Just think what a fraction of big oil profits could have done if they had been used over the last 20 years to foster an economy of experienced and emergency-ready restoration practitioners working continuously to diagnose and repair the ongoing damage to Louisiana's wetlands at the hands of this country's energy production.

We need a full-court press on deepwater oil. We need to think about our personal consumption. Europe overall has half the ecological footprint of the United States for the same standard of living. Government support there for renewable energy technology and infrastructure development has been key. We also need to consider alternative livelihoods for the many people involved in energy production, and about changing federal government policies that give away public resources and provide way too little in terms of oversight and safety requirements. And we need to think about long term strategies for folding the work of restoration into the costs of any type of energy development. As anyone involved in environmental work knows from experience, the sources for change and variability are endless. That doesn't mean that we throw emergency planning out the window. It does mean that we take advantage of what is predictable (for example, sunrises, tides, hurricane season in the Gulf of Mexico) and invest in resilient infrastructure that is built to last with natural variability in mind and as if the future mattered.

\section{Mrill Ingram \\ Editor}

\section{Reference}

Priest, T. 2007. Extraction not creation: The history of offshore petroleum in the Gulf of Mexico. Enterprise \& Society 8:227-267. 